\title{
PERILAKU PEMECAHAN MASALAH SISWA DALAM MENYELESAIKAN MASALAH MATEMATIKA KONTEKSTUAL DITINJAU DARI KECEMASAN MATEMATIKA
}

\author{
Olivia Khufyatul Adhimah \\ Program Studi Pendidikan Matematika, Fakultas Matematika dan Ilmu Pengetahuan Alam, Universitas Negeri Surabaya \\ Email : oliviaadhimah16030174048@mhs.unesa.ac.id
}

\section{Rooselyna Ekawati}

Program Studi Pendidikan Matematika, Fakultas Matematika dan Ilmu Pengetahuan Alam, Universitas Negeri Surabaya Email : rooselynaekawati@unesa.ac.id

\section{Dini Kinati Fardah}

Program Studi Pendidikan Matematika, Fakultas Matematika dan Ilmu Pengetahuan Alam, Universitas Negeri Surabaya Email : dinifardah@unesa.ac.id

\begin{abstract}
Abstrak
Perilaku pemecahan masalah memberikan pemahaman lebih lanjut mengenai perilaku yang siswa lakukan untuk memahami masalah matematika kontekstual dan penyelesaiannya. Perilaku berbeda yang ditunjukkan siswa satu sama lain itu dapat menampakkan bagaimana langkah, kemampuan, serta pemahaman siswa dalam menyelesaikan masalah matematika kontekstual. Penting bagi siswa dan guru untuk mengetahui perilaku pemecahan masalah agar dapat meningkatkan pemahaman dan kemampuan dalam menyelesaikan masalah matematika kontekstual. Kecemasan matematika dapat mempengaruhi siswa saat mencari penyelesaian masalah matematika. Mengingat pentingnya perilaku pemecahan masalah siswa, untuk itu perlu mengetahui perilaku pemecahan masalah siswa dalam menyelesaikan masalah matematika kontekstual ditinjau dari kecemasan matematika. Tujuan dilakukannya penelitian ini ialah untuk mendeskripsikan perilaku pemecahan masalah siswa yang memiliki kecemasan matematika tinggi dan rendah dalam menyelesaikan masalah matematika kontekstual. Subjek dari penelitian ini adalah empat siswa SMP, dengan rincian masing-masing dua siswa dari setiap kelompok kecemasan matematika, tinggi dan rendah. Pengelompokkan kecemasan matematika siswa ditentukan melalui skor angket kecemasan matematika masing-masing siswa. Keempat siswa tersebut diberikan tes pemecahan masalah matematika kontekstual untuk memperoleh data mengenai perilaku pemecahan masalah siswa. Penelitian ini menunjukkan hasil bahwa siswa dengan tingkat kecemasan matematika tinggi masuk kedalam kategori perilaku pemecahan masalah Direct Translation Approach-proficient (DTA-p) dan Direct Translation Approach-not proficient (DTA-np). Untuk siswa dengan kecemasan matematika rendah masuk kedalam kategori Meaning Based Approach-justification (MBA-j). Perbedaan perilaku pemecahan masalah dari dua kategori kecemasan matematika adalah dalam membaca ulang masalah, mengaitkan konsep, memutuskan strategi, menggunakan konteks dalam perhitungan maupun jawaban akhir, dan memberikan penjelasan pada setiap langkah penyelesaian. Perilaku pemecahan masalah dari siswa yang masuk dalam kelompok kecemasan matematika rendah lebih baik dari perilaku pemecahan masalah siswa yang masuk dalam kelompok kecemasan matematika tinggi.
\end{abstract}

Kata Kunci: perilaku pemecahan masalah, masalah matematika kontekstual, kecemasan matematika.

\section{Abstract}

Problem solving behavior make gives better understanding about behavior of students to understand contextual mathematical problems and their solutions. The different behaviors shown by students to each other shows how to steps, abilities, and understanding of students in solving contextual mathematical problems. It is important for students and teachers to know the problem solving behaviors in order to improve understanding and ability to solve contextual mathematical problems. Mathematics anxiety can influence students in soling mathematical problems. Given the importance of students problem solving behavior in learning mathematics, teachers need to know students problem solving behavior in solving contextual mathematical problems based on mathematics anxiety. This study investigate problem solving behavior of students with low and high mathematical anxiety in solving contextual mathematical problems. Subjects in this study were four students of Junior High School, consists each of the two students from each mathematics anxiety group, low and high. Four students were given contextual mathematical problem solving test to investigate about problem solving behavior. Classification of students mathematics anxiety levels is determined through the mathematics anxiety questionnaire score of each student. The results of this research 
showed that students problem solving behavior with high mathematics anxiety were categorized in Direct Translation Approach-proficient (DTA-p) dan Direct Translation Approach-not proficient (DTA-np) category. Students behavior with low mathematics anxiety were categorized in the category of Meaning Based Approach-justification (MBA-j). The difference in problem solving behavior from two categories of mathematics anxiety is in re-reading the problem, linking concepts, deciding strategies, using context in calculations and final answer, and providing an explanation at each step of the solution. Students problem solving behavior with low mathematics anxiety was better than students problem solving behavior with high mathematics anxiety.

Keywords: problem solving behavior, contextual mathematical problems, mathematics anxiety.

\section{PENDAHULUAN}

Melihat banyaknya masalah dalam kehidupan sehari-hari seorang manusia, seseorang dituntut agar cakap dalam menyelesaikan masalah. Keahlian dalam menyelesaikan masalah dapat diperoleh seseorang dengan banyak cara, salah satu cara yang dapat ditempuh adalah dengan belajar matematika. Pernyataan tersebut sesuai dengan tujuan adanya mata pelajaran matematika yang tercantum pada Permendikbud No. 58 tahun 2014 yakni menekankan pada pemecahan masalah yang sangat bermanfaat untuk siswa supaya dapat mengatasi berbagai masalah baik dalam hal matematika ataupun lainnya. Siswono (2008) berpendapat bahwa masalah muncul ketika seseorang dihadapkan pada suatu pertanyaan, kemudian ia tidak dapat menentukan prosedur tertentu untuk digunakan dalam menjawab pertanyaan tersebut. Beberapa masalah matematika terikat dengan konteks yang menyertainya. Menurut Nelissen (1999), konteks merupakan situasi yang menarik bagi siswa dan mereka dapat mengenali sebuah teori, situasi tersebut dapat berupa fiksi atau nyata. Konteks dalam matematika merupakan situasi tertentu atau peristiwa tertentu yang memiliki kaitan dengan konsep matematika (Zulkardi \& Ilma, 2006). Masalah matematika kontekstual merupakan masalah yang memiliki kaitan dengan obyekobyek abstrak dalam matematika dan tidak hanya sebagai masalah yang berhubungan langsung dengan obyek konkret (Anggo, 2011). Sehingga masalah matematika kontekstual adalah masalah matematika yang mengandung situasi atau peristiwa alam yang dapat dikenali oleh siswa.

Terdapat beberapa penelitian yang meneliti tentang pemecahan masalah, salah satunya penelitian mengenai perilaku pemecahan masalah. Penelitian mengenai pemecahan masalah memberikan informasi mengenai proses kognitif yang mengarah pada solusi untuk masalah tersebut. Namun dalam perilaku pemecahan masalah memberikan pemahaman lebih lanjut mengenai perilaku yang siswa lakukan untuk memahami masalah matematika kontekstual dan penyelesaiannya. Memnun dkk (2012) mengemukakan bahwa perilaku pemecahan masalah ialah kegiatan yang dilaksanakan oleh siswa selama siswa tersebut mencari penyelesaian dari suatu masalah dan setiap kegiatan tersebut dibentuk oleh suatu strategi.
Perilaku pemecahan masalah menurut Hegarty dkk (1995) dibagi menjadi 2 kategori yaitu : (1) Pendekatan Langsung (Direct Translation Approach/DTA), dan (2) Pendekatan Bermakna (Meaningful Approach/MA). Kategori pendekatan langsung (Direct Translation Approach/DTA) memiliki karakteristik yakni kurangnya kemampuan siswa dalam mentransformasikan informasi dari masalah yang telah diberikan, termasuk menghubungkan tiap bagian masalah. Siswa mencatat bagian masalah tanpa menggunakan konteks yang digunakan pada masalah. Siswa hanya menuliskan bilangan yang tercantum pada masalah tanpa menggunakan konteks masalah. Akibatnya mereka melakukan perhitungan matematis tanpa membaca ulang masalah. Sedangkan untuk kategori pendekatan bermakna (Meaningful Approach/MA) siswa memiliki perilaku transformatif siswa, yang ditunjukkan oleh tiga perilaku berikut : mencatat informasi yang diberikan dalam masalah, penggunaan konteks masalah, dan memberikan penjelasan dan/atau justifikasi untuk perhitungan matematis. Perilaku yang ditunjukkan siswa pada kategori ini adalah mencatat informasi yang diberikan pada masalah dengan konteks yang sesuai. Salah satu subkategori yang masuk pada kategori ini dapat menuliskan/memberikan penjelasan dan justifikasi untuk langkah perhitungannya. Selain itu, siswa tersebut memahami dan menghubungkannya dengan masalah yang diberikan, ditunjukkan dengan jawaban akhir yang dituliskannya.

Selanjutnya, Pape (2004) mengatakan bahwa klasifikasi perilaku pemecahan masalah tersebut tidak sepenuhnya mengeksploitasi perbedaan halus dalam perilaku pemecahan masalah. Menurut Pape (2004) untuk pendekatan langsung (Direct Translation Approach /DTA) dapat dibagi menjadi 3 sub-kategori yaitu : (1) Direct Translation Approach - not proficient (DTA-np), (2) Direct Translation Approach - proficient (DTA-np), (3) Direct Translation Approach - limited context (DTA-lc). Sedangkan untuk Pendekatan bermakna (Meaning-Based Approach/MBA) dibagi menjadi dua sub-kategori, yaitu : (1) Meaning-Based Approach - full context (MBA-fc), dan

(2) Meaning-Based Approach - justification (MBA-j).

Dalam memecahkan masalah terdapat faktor-faktor yang dapat mempengaruhinya. Rahmat (dalam Winarso, 2014) berpendapat bahwa ada faktor-faktor dalam diri 
siswa yang bisa memengaruhi siswa dalam menyelesaiakan masalah yakni emosi, kepercayaan dan sikap yang salah, kebiasaan, dan motivasi. Emosi mempengaruhi pemecahan masalah seseorang, salah satu bentuk emosi manusia adalah kecemasan. Tatiana dkk (2018) menjelaskan bahwa kecemasan atau biasa disebut anxiety adalah luapan emosi seseorang yang berkaitan dengan rasa tidak aman(takut) akan hal tertentu, bisa jadi penyebab rasa terancam adalah obyek yang tidak jelas. Karena kecemasan adalah salah satu bentuk emosi seseorang, maka kecemasan juga berpengaruh terhadap pemecahan masalah. Terdapat cara mendeteksi gejala kecemasan yang dialami seseorang dengan melihat tiga aspek, yaitu aspek psikologis, aspek fisiologis, dan aspek sosial (Dacey dkk, 2000). Rasa terancam dan rasa takut yang berlebih akan hal tertentu dari seseorang merupakan kecemasan, salah satunya ketakutan pada hal yang berbau matematika atau biasa disebut mathematics anxiety.

Kecemasan matematika adalah perasaan ketakutan ketika dihadapkan dengan masalah matematika (Zakaria \& Nordin, 2008). Hal tersebut mengindikasikan bahwa kecemasan matematika pada siswa akan muncul ketika siswa dihadapkan pada situasi dimana siswa tersebut diharuskan untuk dapat menyelesaikan persoalan yang berhubungan dengan matematika termasuk masalah matematika. Selain itu, Freedman (2017) mengemukakan kecemasan matematika merupakan bentuk emosi seseoran jika dihadapkan dengan matematika karena terdapat pengalaman buruk di masa lalu dan emosi tersebut mengganggu pembelajaran matematika setelahnya. Karena kecemasan matematika juga merupakan bentuk emosi seseorang, maka kecemasan matematika dapat mempengaruhi pemecahan masalah matematika.

Mahmood \& Khatoon (2011) membagi dua kategori kecemasan matematika yaitu kategori kecemasan matematika tinggi dan kategori kecemasan matematika rendah. Terdapat penelitian oleh Karasel dkk (2010) mengenai keterkaitan antara kecemasan matematika dan kemampuan siswa dalam memecahkan masalah yang menghasilkan korelasi negatif antara keduanya. Hal tersebut sejalan dengan Aunurrofiq \& Junaedi (2017) yang menyatakan bahwa kecemasan matematika mempunyai hubungan linear dengan kemampuan siswa saat melakukan pemecahan masalah dan hubungannya bersifat negatif sehingga bila siswa memiliki kecemasan matematika tinggi mengakibatkan kemampuan pemecahan siswa rendah.

Dalam penelitian ini menggunakan masalah matematika kontekstual pada materi perbandingan. Dapat diketahui persentase siswa menjawab benar pada salah satu soal ujian nasional materi perbandingan adalah $28,23 \%$. Hal tersebut menunjukkan bahwa banyak siswa menjawab salah pada soal materi perbandingan, itu menandakan masalah perbandingan menyulitkan bagi siswa. Salah satu kesulitan siswa dalam mencari penyelesaian masalah perbandingan adalah memahami masalah. Pernyataan tersebut sejalan dengan Hardi, dkk (2013) yang mengemukakan bahwa kesulitan yang dialami siswa adalah kesulitan menafsirkan apa yang ditanyakan pada soal. Masalah matematika pada materi perbandingan seringkali dijumpai pada kehidupan sehari-hari, sehingga masalah perbandingan terikat dengan konteks yang menyertainya. Hal tersebut sejalan dengan Avcu \& Avcu (2010) yang mengemukakan bahwa konsep dari ratio dan proporsi banyak digunakan pada pembelajaran matematika, sains dan juga pada kehidupan sehari-hari. Selain itu, menurut Wahyuningrum (2019) siswa kurang pengalaman dalam mengeksplorasi konteks dalam materi perbandingan.

Berdasarkan penjelasan di atas, tujuan dilakukannya penelitian ini adalah untuk mengetahui perilaku pemecahan masalah siswa yang mengalami kecemasan matematika tinggi dalam menyelesaikan masalah matematika kontekstual dan perilaku pemecahan masalah siswa yang memiliki kecemasan matematika rendah dalam menyelesaikan masalah matematika kontekstual.

\section{METODE}

Penelitian ini adalah jenis penelitian deskriptif. Pendekatan penelitian dari penelitian ini merupakan pendekatan kualitatif. Sumber data dari penelitian ini adalah 45 siswa Sekolah Menengah Pertama di Surabaya. Subjek penelitian dipilih sebanyak empat subjek, terdiri dari masing-masing dua subjek dari setiap kategori kecemasan matematika yakni, kategori tinggi dan rendah. Untuk pengumpulan data, 45 siswa tersebut diberikan angket kecemasan matematika. Setelah itu dipilih empat subjek dengan dua subjek yang memiliki skor angket tertinggi dan dua subjek yang memiliki skor angket terendah. Kemudian empat subjek tersebut diberikan tes pemecahan masalah dan diwawancarai mengenai penyelesaian tes pemecahan masalah tersebut.

Dalam penelitian ini data yang akan diperoleh yaitu data hasil angket kecemasan matematika, data hasil tes perilaku pemecahan masalah matematika kontekstual, dan data hasil wawancara. Data hasil angket kecemasan matematika digunakan untuk mengelompokkan subjek berdasarkan skor kecemasan matematika yang dimiliki siswa. Angket kecemasan matematika diadaptasi dari angket Math Anxiety Scale (MAS) oleh Mahmood \& Khatoon (2011). Pengelompokkan kecemasan matematika berdasarkan Mahmood \& Khatoon (2011) yang membagi kecemasan matematika menjadi dua kelompok. Siswa dapat dikategorikan memiliki kecemasan matematika tinggi jika, $42 \leq$ Skor angket $\leq 70$, sedangkan siswa dapat dikategorikan memiliki kecemasan matematika rendah jika, $14 \leq$ Skor angket $<42$. 
Data hasil tes pemecahan masalah matematika kontekstual digunakan untuk mengetahui perilaku pemecahan masalah siswa saat mencari penyelesaian dari masalah matematika kontekstual. Data hasil tes pemecahan masalah dianalisis menggunakan indikator dari Pape (2004). Data hasil wawancara digunakan untuk mendapatkan informasi lebih lanjut mengenai perilaku pemecahan masalah siswa saat mencari solusi dari permasalahan matematika kontekstual. Analisis data dilakukan dengan reduksi data, penyajian data, dan penarikan kesimpulan. Berikut indikator perilaku pemecahan masalah siswa dalam menyelesaikan masalah matematika kontekstual yang diadaptasi dari Pape (2004).

Tabel 1 Indikator Perilaku Pemecahan Masalah

\begin{tabular}{|c|c|c|c|c|c|c|}
\hline \multirow{2}{*}{\multicolumn{2}{|c|}{$\begin{array}{l}\text { Indikator Perilaku } \\
\text { Pemecahan Masalah }\end{array}$}} & \multicolumn{5}{|c|}{ Kategori Perilaku Pemecahan Masalah } \\
\hline & & \multirow{2}{*}{$\begin{array}{c}\text { DTA-p } \\
\mathrm{Ya}\end{array}$} & \multirow{2}{*}{$\begin{array}{c}\begin{array}{c}\text { DTA- } \\
\text { np }\end{array} \\
\\
\text { Tidak }\end{array}$} & \multirow{2}{*}{$\begin{array}{r}\text { DTA-lc } \\
\text { Ya }\end{array}$} & \multirow{2}{*}{$\begin{array}{c}\begin{array}{c}\text { MBA- } \\
\text { fc }\end{array} \\
\\
Y a\end{array}$} & \multirow{2}{*}{$\begin{array}{r}\text { MB } \\
\text { A-j } \\
\\
Y a\end{array}$} \\
\hline 1. & $\begin{array}{l}\text { Menyebutkan } \\
\text { informasi yang } \\
\text { diperoleh dari } \\
\text { masalah } \\
\text { menggunakan } \\
\text { kalimat sendiri } \\
\text { dengan benar }\end{array}$ & & & & & \\
\hline 2. & $\begin{array}{l}\text { Membaca ulang } \\
\text { informasi yang } \\
\text { tersedia dalam } \\
\text { masalah }\end{array}$ & Tidak & Tidak & & Ya & $\mathrm{Ya}$ \\
\hline 3. & $\begin{array}{l}\text { Mengaitkan fakta, } \\
\text { konsep, prinsip, } \\
\text { atau prosedur yang } \\
\text { digunakan dengan } \\
\text { konteks masalah }\end{array}$ & Tidak & Tidak & & & Ya \\
\hline 4. & $\begin{array}{l}\text { Memutuskan } \\
\text { strategi yang tepat } \\
\text { untuk } \\
\text { menyelesaikan } \\
\text { masalah }\end{array}$ & Tidak & Tidak & & a & $\mathrm{Ya}$ \\
\hline 5. & $\begin{array}{l}\text { Menggunakan } \\
\text { konteks masalah } \\
\text { dalam melakukan } \\
\text { perhitungan }\end{array}$ & Tidak & Tidak & $\mathrm{Ya}$ & $\mathrm{Y}$ & Ya \\
\hline 6. & $\begin{array}{l}\text { Menggunakan } \\
\text { konteks masalah } \\
\text { pada jawaban akhir } \\
\text { sebagai solusi dari } \\
\text { masalah }\end{array}$ & $\mathrm{Ya}$ & Tidak & & Ya & Ya \\
\hline 7. & $\begin{array}{l}\text { Memberikan } \\
\text { penjelasan logis } \\
\text { untuk setiap } \\
\text { langkah perhitungan }\end{array}$ & Tidak & Tidak & Tidak & Tidak & $\mathrm{Ya}$ \\
\hline
\end{tabular}

Berikut merupakan masalah matematika kontekstual yang digunakan dalam penelitian ini.

1. Seorang guru akan memesan pizza untuk siswa kelas 7A. Untuk memudahkan dalam pengumpulan uang dan pembagian pizza, guru tersebut membagi siswanya dalam 2 kelompok. Kelompok pertama beranggotakan 18 orang membeli 3 signature pizza ukuran reguler berdiameter $25 \mathrm{~cm}$ dengan original crust, sedangkan kelompok 2 beranggotakan 16 orang membeli 2 signature pizza ukuran jumbo berdiameter $35 \mathrm{~cm}$ dengan original crust. Jika dikesempatan lain terjadi hal yang sama seperti pada kejadian diatas, manakah kelompok yang akan kamu pilih agar kamu mendapat keuntungan? Berikan alasannya.

\section{HASIL DAN PEMBAHASAN}

Berdasarkan analisis data angket kecemasan matematika

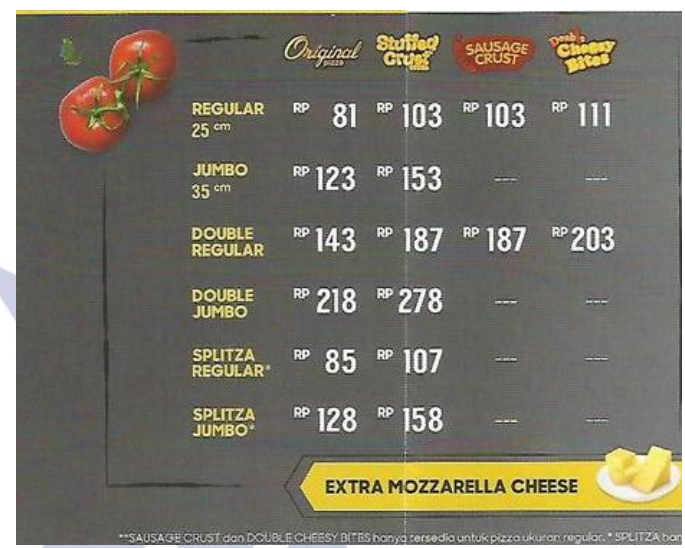

Gambar 1 Harga Pizza

yang telah diberikan kepada 45 siswa. Pengelompokkan kecemasan matematika menggunakan ketentuan skor dari Mahmood \& Khatoon (2011). Didapatkan sebanyak 22 siswa yang masuk dalam kategori kecemasan matematika tinggi dan sebanyak 23 siswa yang tergolong kecemasan matematika rendah. Telah dipilih 4 subjek dengan rincian, masing-masing dua subjek pada setiap kelompok kecemasan matematika. SKT = Subjek dengan Kecemasan Matematika Tinggi, SKR = Subjek dengan Kecemasan Matematika Rendah. Selanjutnya analisis hasil tes pemecahan masalah matematika menggunakan indikator dari Pape (2004).

Tabel 2 Hasil Pengkategorian Perilaku Pemecahan Masalah Subjek Penelitian

\begin{tabular}{|c|c|c|c|c|}
\hline $\begin{array}{c}\text { Indikator } \\
\text { Perilaku } \\
\begin{array}{c}\text { Pemecahan } \\
\text { Masalah }\end{array}\end{array}$ & \multicolumn{4}{|c|}{ Subjek Penelitian } \\
\cline { 2 - 5 } & SKT1 & SKT2 & SKR1 & SKR2 \\
\hline 1 & Ya & Tidak & Ya & Ya \\
\hline 2 & Tidak & Tidak & Ya & Ya \\
\hline 3 & Tidak & Tidak & Ya & Ya \\
\hline 4 & Tidak & Tidak & Ya & Ya \\
\hline 5 & Tidak & Tidak & Ya & Ya \\
\hline 6 & Ya & Tidak & Ya & Ya \\
\hline 7 & Tidak & Tidak & Ya & Ya \\
\hline $\begin{array}{c}\text { Kategori } \\
\text { Perilaku }\end{array}$ & DTA-p & DTA-np & MBA-j & MBA-j \\
\hline
\end{tabular}




\begin{tabular}{|c|l|l|l|l|}
\hline $\begin{array}{c}\text { Pemecahan } \\
\text { Masalah }\end{array}$ & & & & \\
\hline
\end{tabular}

Tabel 2 menunjukkan masing-masing kategori perilaku pemecahan masalah dari keempat subjek. Perilaku pemecahan masalah subjek yang memiliki kecemasan matematika tinggi masuk kedalam kategori DTA-p dan DTA-np. Perilaku pemecahan masalah subjek yang memiliki kecemasan matematika rendah masuk kedalam kategori MBA-j.

\section{Perilaku Pemecahan Masalah Siswa dengan Kecemasan Matematika Tinggi}

Siswa yang termasuk dalam golongan kecemasan matematika tinggi yaitu SKT1 dan SKT2. Terdapat perbedaan kategori perilaku pemecahan masalah dari SKT1 dan SKT2. SKT1 masuk dalam kategori DTA-p, sedangkan SKT2 masuk dalam kategori DTA-np.

Dalam menyebutkan informasi yang diperoleh dari masalah, SKT1 dan SKT2 terdapat perbedaan. Berikut disajikan petikan wawancara dengan SKT1 dan SKT2,

$$
\begin{aligned}
& \mathrm{P} \quad \text { : Coba jelaskan maksud dari soal tersebut? } \\
& \text { SKT1 : Kelompoknya ada dua, kelompok }
\end{aligned}
$$

Berdasarkan kutipan wawancara diatas, SKT1 dapat menyebutkan seluruh informasi yang diketahui dalam masalah tersebut, antara lain banyak anggota tiap kelompok, banyak pizza yang dibeli, jenis pizza yang dibeli, ukuran pizza yang dibeli, dan harga pizza.

$$
\begin{array}{lll}
\text { P } & : & \text { Apa maksud dari soal tersebut ? } \\
\text { SKT2 } & : & \text { Membeli pizza } \\
\mathrm{P} & : & \text { Apa yang ditanyakan dari soal tersebut ? } \\
\text { SKT2 } & : & \text { Disuruh mencari kelompok mana yang } \\
& \text { mendapat keuntungan } \\
\text { P } & : & \text { Apa diketahui dari soal tersebut ? } \\
\text { SKT2 } \quad: & \text { Terdapat } 2 \text { kelompok membeli pizza } \\
& \text { membeli pizza signature, kelompok 1 } \\
& \text { beranggotakan } 18 \text { orang membeli } 3 \text { pizza } \\
& \text { dengan ukuran diameter } 25 \text { cm selanjutnya } \\
& \text { kelompok } 2 \text { beranggotakan } 16 \text { orang } \\
& \text { membeli } 2 \text { pizza dengan ukuran diameter } \\
& 35 \mathrm{~cm} .
\end{array}
$$

$\mathrm{P}$ gambar tersebut?

SKT2 : Belum tahu

Dari kutipan wawancara diatas, SKT2 hanya menyebutkan banyak anggota tiap kelompok, banyak pizza yang dibeli, dan ukuran pizza yang dibeli, SKT2 tidak dapat menyebutkan informasi mengenai harga pizza yang tertera pada gambar dalam masalah tersebut. Dalam membaca ulang soal SKT1 dan SKT2 sama-sama tidak membaca ulang soal tersebut. Keduanya hanya membaca soal sebanyak satu kali.

Dalam menyelesaikan masalah matematika kontekstual tersebut, SKT1 membandingkan iuran masing-masing orang pada dua kelompok tersebut. Gambar 2

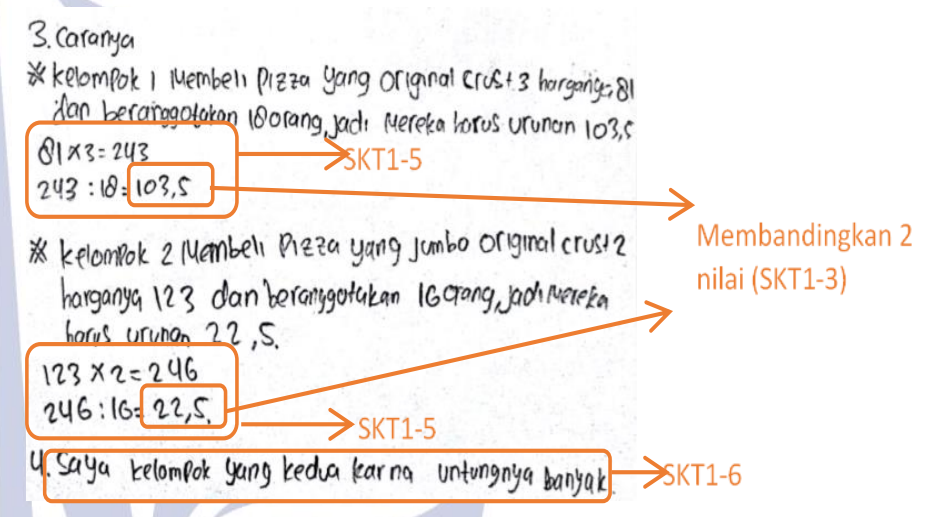

menunjukkan hasil pengerjaan SKT1.

Gambar 2 Hasil Pengerjaan SKT1

Dari hasil pengerjaan SKT1 diatas, SKT1 hanya dapat mengaitkan konsep perbandingan (SKT1-3) untuk menyelesaikan masalah tersebut, ia membandingkan iuran masing-masing orang antara dua kelompok. Seharusnya masalah tersebut juga dikaitkan dengan luas lingkaran untuk mengetahui luasan yang didapatkan untuk setiap orangnya. Hal tersebut menunjukkan bahwa SKT1 tidak dapat mengaitkan fakta, konsep, prinsip, atau prosedur yang digunakan untuk menyelesaikan masalah tersebut. Untuk menentukan kelompok yang lebih mendapatkan keuntungan SKT1 menggunakan strategi dengan menghitung iuran yang harus dibayar oleh masing-masing orang dan membandingkan iuran antara dua kelompok tersebut. Sebenarnya strategi tersebut dapat digunakan, tetapi harus membandingkan juga ukuran pizza yang didapatkan untuk setiap orangnya. Hal itu menunjukkan bahwa SKT1 tidak dapat memutuskan strategi yang tepat untuk menentukan penyelesaian dari masalah tersebut. 
SKT2 dalam menyelesaikan masalah tersebut dengan membandingkan ukuran diameter pizza yang dibeli oleh dua kelompok tersebut. Gambar 3 menunjukkan hasil pengerjaan SKT2.

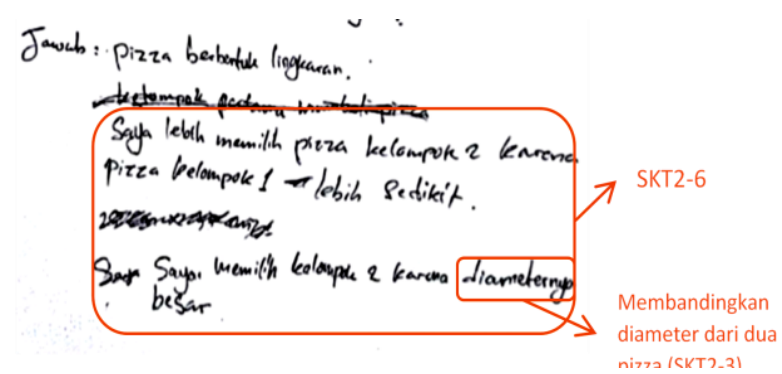

Gambar 3 Hasil Pengerjaan SKT

Dari hasil pengerjaan SKT2 diatas, SKT2 juga hanya dapat mengaitkan konsep perbandingan (SKT2-3) untuk menyelesaikan masalah tersebut, tetapi ia hanya membandingkan diameter pizza yang dibeli oleh dua kelompok tersebut. Seharusnya ia membandingkan harga per $\mathrm{cm}^{2}$ dari pizza yang dibeli oeh dua kelompok tersebut. Hal tersebut menunjukkan bahwa SKT2 tidak dapat mengaitkan fakta, konsep, prinsip, atau prosedur yang digunakan untuk menyelesaikan masalah tersebut. Untuk menentukan kelompok yang lebih mendapatkan keuntungan SKT2 menggunakan strategi dengan membandingkan ukuran diameter pizza yang dibeli oleh kedua kelompok tersebut. Strategi tersebut kurang tepat untuk menyelesaikan masalah tersebut, karena masih ada beberapa informasi pada soal harus digunakan untuk menyelesaikan masalah tersebut seperti, harga pizza. Berdasarkan penjelasan di atas dapat diperoleh SKT2 tidak dapat memutuskan strategi yang tepat untuk menyelesaiakan masalah tersebut.

Dapat dilihat pada jawaban SKT1 pada Gambar 2, terlihat bahwa SKT1 mengalikan perhitungan hanya mengalikan dua bilangan dan melakukan pembagian (SKT1-5). Dalam perhitungan yang dilakukan oleh SKT1 tidak menuliskan besaran maupun menjelaskan perhitungan tersebut untuk mencari nilai apa. Hal tersebut menunjukkan bahwa SKT1 tidak menggunakan konteks masalah dalam melakukan perhitungan. Untuk SKT2, terlihat pada Gambar 3 ia tidak melakukan perhitungan melainkan hanya membandingkan diameter pizza yang dipilih pada masing-masing kelompok. Itu berarti bahwa SKT2 juga tidak menggunakan konteks masalah untuk melakukan perhitungan tersebut.

Dalam menuliskan jawaban akhir, SKT1 menjawab soal tersebut dengan memilih kelompok 2 (SKT1-6). Alasan SKT1 memilih kelompok 2 terdapat pada kutipan transkrip wawancara berikut.

$\begin{array}{lll}\text { P } & : \text { Apa jawaban dari soal tersebut? } \\ \text { KT1 } & : \text { Jawabannya kelompok dua } \\ \text { P } & : \text { Mengapa? } \\ \text { SKT1 } & : \text { Karena untungnya lebih banyak }\end{array}$

P : Kamu bisa mengatakan untungnya lebih banyak dari bilangan yang mana?

SKT1 : Karena dari pembagian harga per orang. Untuk kelompok satu didapatkan 103,5 dan kelompok dua 22,5. Yang lebih kecil yang saya pilih. Karena iurannya lebih kecil maka lebih menguntungkan kelompok 2.

Berdasarkan kutipan wawancara dengan SKT1 tersebut, SKT1 memilih kelompok 2 dengan alasan kelompok 2 memiliki untung lebih besar karena iuran yang dibayarkan kelompok 2 lebih sedikit dibandingkan kelompok 1. Hal tersebut menunjukkan bahwa SKT1 menggunakan konteks pada jawaban akhir sebagai solusi dari masalah tersebut. Untuk SKT2, ia menjawab memilih kelompok 2 (SKT2-6). Pada Gambar 3 ia menuliskan memilih kelompok 2 dengan alasan banyak pizza kelompok 1 lebih sedikit dengan kelompok 2. Banyak pizza pada kelompok 1 yang tertera pada soal lebih banyak dibanding kelompok 2, kelompok 1 membeli 3 pizza sedangkan kelompok 2 membeli 2 pizza. Hal tersebut menunjukkan bahwa SKT2 tidak menggunakan konteks pada jawaban akhir sebagai solusi dari masalah tersebut.

Dari jawaban pada Gambar 2 dan hasil wawancara, SKT1 tidak dapat mengemukakan penjelasan pada setiap langkah perhitungan yang dilakukan. Untuk membandingkan kedua bilangan akhir yang didapatkan, SKT1 tidak memperdulikan luasan yang diterima masingmasing orang sama atau tidak. Hal tersebut berarti SKT1 membandingkan kedua bilangan yang belum setara. Dapat disimpulkan bahwa SKT1 tidak memberikan penjelasan logis untuk setiap langkah perhitungan yang dilakukan. Dari jawaban pada Gambar 3 dan hasil wawancara, SKT2 tidak dapat mengemukakan penjelasan pada setiap langkah perhitungan yang dilakukan. Untuk membandingkan diameter pizza yang dibeli oleh masing-masing kelompok, SKT2 beralasan karena dengan menggunakan diameter lebih mudah dan informasi tersebut sudah tertera pada soal. Dapat disimpulkan bahwa SKT2 tidak memberikan penjelasan logis untuk setiap langkah perhitungan yang dilakukan.

Gejala kecemasan matematika yang ditunjukkan oleh siswa dapat tercermin pada saat wawancara. SKT1 pada saat diwawancarai, ia gemetar dan sampai berkeringat pada tangan dan bagian wajah. Untuk SKT2 terlihat tidak fokus saat diwawancara dan ingin cepat mengakhiri tes penyelesaian tersebut atau dapat dikatakan tidak ingin berlama-lama dengan masalah matematika. Hal itu sejalan dengan Dacey (2000) bahwa gejala kecemasan matematika dapat dilihat dari aspek fisiologis. 
Dari perilaku pemecahan masalah yang ditunjukkan dan berdasarkan kategori perilaku pemecahan masalah siswa dalam Pape (2004), SKT1 masuk dalam kategori Direct Translation Approach - proficient (DTA-p) dan SKT2 masuk dalam kategori Direct Translation Approach - not proficient (DTA-np). Hal itu sejalan dengan hasil penelitian yang didapatkan oleh Adhimah \& Ekawati (2020). Hasil penelitian tersebut menerangkan perilaku pemecahan masalah siswa dengan kecemasan matematika tinggi masuk kedalam kategori Direct Translation Approach - not proficient (DTA-np) dan ada pula yang masuk dalam kategori Direct Translation Approach proficient (DTA-p). Selain itu, pada penelitian Aziz, dkk (2018) mengemukakan bahwa siswa dengan kemampuan matematika rendah masuk kedalam kategori perilaku Direct Translation Approach-proficient (DTA-p). Kecemasan matematika yang dimiliki siswa dapat mempengaruhi kemampuan matematika siswa, semakin tinggi kecemasan matematika siswa akan menurunkan kemampuan matematika siswa (Auliya, 2016). Berdasarkan hal tersebut dan kategori perilaku pemecahan masalah dari Hegarty dkk (1995) dan Pape (2004) dapat disimpulkan bahwa siswa yang mengalami kecemasan matematika tinggi cenderung masuk dalam kelompok Direct Translation Approach (Pendekatan Langsung).

\section{Perilaku Pemecahan Masalah Siswa dengan Kecemasan Matematika Rendah}

Siswa yang termasuk dalam golongan kecemasan matematika rendah yaitu SKR1 dan SKR2. Perilaku pemecahan masalah SKR1 dan SKR2 masuk pada kategori yang sama yaitu MBA-j. Dalam menyebutkan informasi SKR1 dan SKR2 bisa menyebutkan informasi yang diperoleh dari soal tersebut dengan benar. SKR1 dan SKR2 dapat menyebutkan seluruh informasi yang diketahui dalam masalah tersebut, antara lain banyak anggota tiap kelompok, banyak pizza yang dibeli, jenis pizza yang dibeli, ukuran pizza yang dibeli, dan harga pizza. Hal tersebut tercermin dari kutipan wawancara berikut ini.

$\mathrm{P} \quad$ : Coba jelaskan apa yang dimaksud dari soal tersebut?

SKR1 : Kita harus memilih kelompok yang lebih mendapat keuntungan

$\mathrm{P} \quad$ : Apa yang diketahui dalam soal tersebut?

SKR1 : Jumlah anggota, diameter pizza, ukuran pizza, jenis pizza, jumlah orang dalam satu kelompok

$\mathrm{P} \quad$ : Apa yang bisa kamu dapatkan dari gambar tersebut?

SKR1 : Harga tiap jenis pizza

Keduanya juga membaca ulang setiap informasi yang disajikan dalam masalah. Dalam membaca sebelum menyelesaikan masalah tersebut SKR1 tercacat memerlukan waktu selama 2 menit 20 detik sedangkan untuk SKR2 memerlukan waktu selama 1 menit 4 detik. SKR1 dan SKR2 juga membaca kembali soal saat menyelesaikan masalah tersebut.

Dalam menyelesaikan masalah matematika kontekstual tersebut, SKR1 membandingkan harga per luasan pizza yang dibeli oleh dua kelompok tersebut. Gambar 4 menunjukkan hasil pengerjaan SKR1.

Berdasarkan hasil pengerjaan pada Gambar 4, SKR1 mengaitkan perbandingan (SKR1-3b) dan lingkaran (SKR2-3a) untuk menyelesaikan masalah tersebut. SKR1

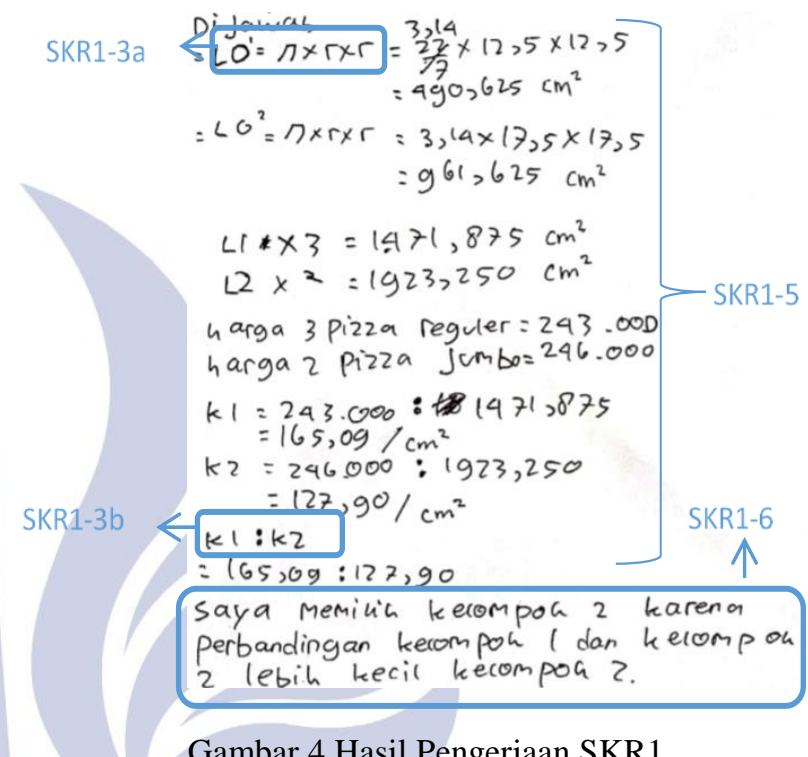

Gambar 4 Hasil Pengerjaan SKR1

mengaitkan lingkaran dengan konteks masalah untuk menentukan luasan pizza dan mengaitkan perbandingan untuk menentukan kelompok mana yang lebih menguntungkan. Hal tersebut menunjukkan bahwa SKR1 dapat mengaitkan fakta, konsep, prinsip atau prosedur yan digunakan dengan konteks masalah. Untuk menentukan kelompok yang lebih mendapatkan keuntungan SKR1 menggunakan strategi dengan menentukan harga perluasan masing-masing pizza dari setiap kelompok. Untuk SKR1 melibatkan banyak pizza yang dibeli oleh masing-masing kelompok dalam perhitungannya. Maka, luasan pizza tersebut dikalikan dengan banyaknya pizza. Sama halnya dengan harga pizza juga akan dikalikan dengan banyak pizza. Strategi yang digunakan merupakan strategi yang tepat untuk menyelesaikan masalah tersebut. Hal itu berarti SKR1 dapat memutuskan strategi yang tepat untuk menyelesaikan masalah. 
Dalam menyelesaikan masalah matematika kontekstual tersebut, SKR2 membandingkan harga per luasan pizza yang dibeli oleh dua kelompok tersebut. Gambar 5 menunjukkan hasil pengerjaan SKR2.

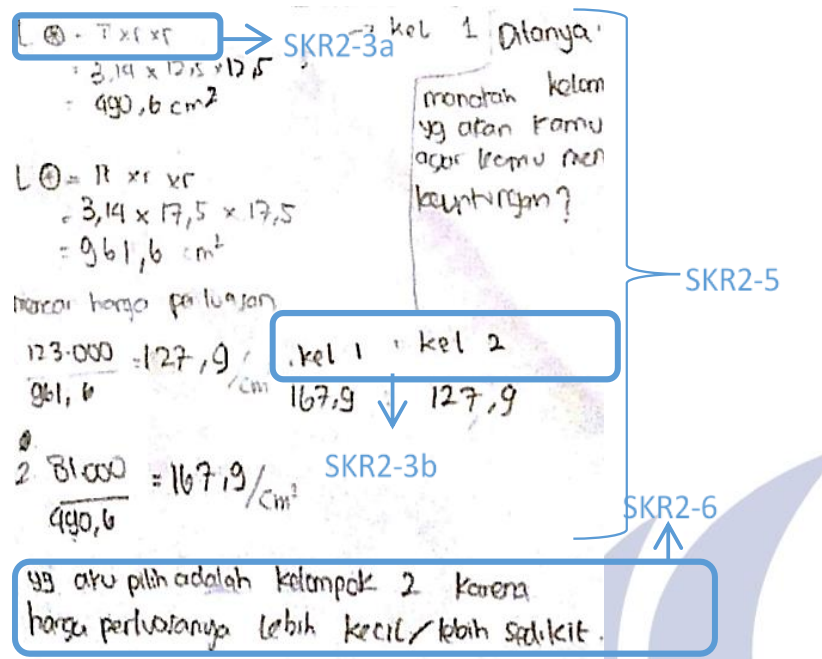

Gambar 5 Hasil Pengerjaan SKR2

Berdasarkan hasil pengerjaan pada Gambar 5, SKR2 mengaitkan perbandingan (SKR2-3b) dan lingkaran (SKR2-3a) untuk menyelesaikan masalah tersebut. SKR2 mengaitkan lingkaran dengan konteks masalah untuk menentukan luasan pizza dan mengaitkan perbandingan untuk menentukan kelompok mana yang lebih menguntungkan. Hal tersebut menunjukkan bahwa SKR2 dapat mengaitkan fakta, konsep, prinsip atau prosedur yan digunakan dengan konteks masalah. Untuk menentukan kelompok yang lebih mendapatkan keuntungan SKR2 menggunakan strategi dengan menentukan harga perluasan masing-masing pizza dari setiap kelompok. Berbeda halnya dengan yang dilakukan SKR1, SKR2 menyelesaikan masalah tersebut dengan memandang satu buah pizza. Begitu juga dengan harga pizza, SKR2 hanya menggunakan harga pizza yang tertera tanpa mengalikan dengan banyak pizza yang dibeli. Strategi yang digunakan SKR2 merupakan strategi yang tepat untuk menyelesaikan masalah tersebut. SKR2 dapat memutuskan strategi yang tepat untuk menyelesaikan masalah.

Dalam menggunakan konteks pada perhitungan, SKR1 dan SKR2 melakukan perhitungan dengan jelas menuliskan apa yang dicari serta diikuti dengan rumus yang digunakan terlihat pada Gambar 4 (SKR1-5) dan Gambar 5 (SKR2-5). Selain itu, keduanya juga menuliskan besaran dari bilangan yang diperoleh, misal $\mathrm{cm}^{2}$. Hal tersebut menunjukkan bahwa SKR1 dan SKR2 menggunakan konteks masalah dalam melakukan perhitungan. Dalam menggunakan konteks pada jawaban akhir, SKR1 dan SKR2 telah menjawab soal tersebut dengan benar dan menuliskan jawaban akhir tersebut menggunakan konteks (SKR1-6, SKR2-6). Dapat disimpulkan bahwa SKR1 dan SKR2 menggunakan konteks pada jawaban akhir sebagai solusi dari masalah tersebut.

Dalam memberikan penjelasan logis, SKR1 dan SKR2 dapat memberikan penjelasan pada setiap langkah perhitungan yang dilakukan. Penjelasan tersebut antara lain penjelasan mengenai alasan penggunaan konsep perbandingan, luas linkaran, dan alasan memilih kelompok 2 sebagai solusi dari masalah tersebut. Berikut penjelasan pada setiap langkah perhitungan dari SKR2.

$\mathrm{P} \quad$ : Konsep apa yang kamu gunakan dalam penyelesaian dan apa kaitannya?

SKR2 : Untuk mencari luas pizzanya karena bentuk pizza adalah lingkaran. Dan, perbandingan agar bisa mengetahui nilai yang paling sedikit

$\mathrm{P} \quad$ : Mengapa mencari nilai yang paling sedikit?

SKR2 : Agar mendapat keuntungan yang besar. Karena harga perluasannya lebih murah. Jadi lebih menguntungkan untuk pembeli.

Keduanya memberikan penjelasan yang tepat untuk masing-masing alasan tersebut, diantaranya alasan penggunaan luas lingkaran dikarenakan bentuk pizza adalah lingkaran, alasan penggunaan konsep perbandingan dikarenakan untuk memilih kelompok mana yang memiliki keuntungan lebih besar dan keuntungan lebih besar dapat diketahui dari nilai (harga per luasan pizza) yang terkecil diantara kedua kelompok tersebut. Dapat disimpulkan bahwa SKR1 dan SKR2 dapat memberikan penjelasan logis untuk setiap langkah perhitungan.

Dari perilaku pemecahan masalah yang ditunjukkan dan kategori perilaku pemecahan masalah dari Pape (2004), SKR1 dan SKR2 masuk dalam kategori Meaning Based Approach - justification (MBA-j). Hasil penelitian tersebut serupa dengan penelitian Aziz, dkk (2018) yang mengemukakan siswa dengan kemampuan matematika tinggi masuk kedalam kategori perilaku pemecahan masalah Meaning Based Approach - justification (MBAj). Kecemasan matematika yang dimiliki siswa dapat memengaruhi kemampuan matematikanya, semakin tinggi kecemasan matematika siswa akan semakin menurun kemampuan matematikanya (Auliya, 2016). Berdasarkan hasil penelitian tersebut dan kategori perilaku pemecahan masalah dari Hegarty dkk (1995) dan Pape (2004), dapat disimpulkan bahwa siswa dengan kecemasan matematika rendah cenderung masuk dalam kelompok Meaning Based Approach (Pendekatan Bermakna).

Hasil penelitian yang telah dilakukan oleh Aunurrofiq \& Junaedi (2017) dan Karasel dkk (2010) menunjukkan hasil, siswa yang mengalami kecemasan matematika tinggi mempunyai tingkat kemampuan untuk memecahkan masalah yang rendah dan siswa dengan kecemasan matematika rendah mempunyai tingkat kemampuan pemecahan masalah yang tinggi. Hasil penelitian tersebut memerkuat hasil penelitian ini yang memperlihatkan 
bahwa siswa dengan kecemasan matematika yang rendah masuk dalam kategori Meaning Based Approachjustification (MBA-j) yang merupakan kategori paling tinggi dalam kategori perilaku pemecahan masalah, sedangkan siswa yang memiliki kecemasan matematika tinggi masuk dalam kategori Direct Translation Approach - not proficient (DTA-np) dan Direct Translation Approach - proficient (DTA-p) yang merupakan kategori dua terendah dari kategori perilaku pemecahan masalah. Pernyataan tersebut menunjukkan bahwa perilaku pemecahan masalah siswa yang termasuk pada kelompok kecemasan matematika rendah lebih baik dibanding perilaku pemecahan masalah siswa yang termasuk dalam kelompok kecemasan matematika tinggi.

\section{PENUTUP}

\section{Simpulan}

Dari hasil penelitian dan pembahasan menampakkan adanya perbedaan perilaku pemecahan masalah siswa dalam menyelesaikan masalah matematika kontekstual dari kelompok tinggi dan rendah. Kategori perilaku pemecahan masalah siswa yang mempunyai kecemasan matematika tinggi yaitu Direct Translation Approach-not proficient (DTA-np) dan Direct Translation Approach-proficient (DTA-p). Untuk siswa berkecemasan matematika rendah masuk dalam kategori Meaning-Based Approachjustification (MBA-j).

Perilaku pemecahan masalah siswa yang mengalami kecemasan matematika tinggi dalam mencari penyelesaian masalah matematika kontekstual disajikan sebagai berikut: (1) siswa masih memiliki kesulitan dalam mengungkapkan informasi yang diperoleh dari masalah tersebut; (2) siswa tidak membaca ulang informasi yang tersedia dalam masalah yang disajikan; (3) siswa tidak mengaitkan fakta, konsep, prinsip, atau prosedur dalam penyelesaian masalah tersebut dengan konteks masalah yang ada (siswa hanya dapat mengaitkan masalah dengan perbandingan); (4) siswa yang memiliki kecemasan matematika tinggi tidak mampu memutuskan strategi yang tepat untuk mencari solusi dari masalah tersebut; (5) siswa tersebut juga tidak menggunakan konteks dalam melakukan perhitungan; (6) siswa dengan tingkat kecemasan matematika tinggi, ada yang menuliskan jawaban akhir menggunakan konteks dan ada yang tidak menggunakan konteks pada jawaban akhirnya; (7) siswa dengan tingkat kecemasan tinggi tidak dapat memberikan penjelasan logis untuk setiap langkah perhitungan yang dilakukan.

Perilaku pemecahan masalah siswa yang masuk dalam kelompok kecemasan matematika rendah saat menyelesaikan masalah matematika kontekstual adalah sebagai berikut : (1) siswa yang mengalami kecemasan matematika rendah dapat menyebutkan informasi yang diperoleh dari masalah yang disajikan dengan benar. (2) siswa tersebut membaca informasi yang tersedia dalam masalah yang disajikan. (3) siswa tersebut juga dapat mengaitkan fakta, konsep, prinsip, atau prosedur yang digunakan untuk menyelesaikan masalah (dalam masalah penelitian ini siswa dapat mengaitkan konsep lingkaran dan perbandingan untuk menuntaskan masalah tersebut). (4) siswa tersebut juga dapat memutuskan strategi yang tepat untuk mencari solusi dari masalah tersebut. (5) siswa tersebut menggunakan konteks dalam melakukan perhitungan dapat dilihat pada perhitungan yang dilakukan jelas untuk mencari nilai apa dan menuliskan besaran dari nilai yang dihasilkan. (6) siswa menggunakan konteks masalah pada jawaban akhir sebagai solusi dari masalah tersebut. (7) siswa dengan kecemasan matematika rendah dapat memberikan penjelasan logis untuk setiap langkah perhitungan yang dilakukannya.

\section{Saran}

Dari hasil penelitian diperoleh masih terdapat siswa yang perilaku pemecahan masalahnya masuk pada kategori Direct Translation Approach-not proficient (DTA-np) yakni kategori terendah dari perilaku pemecahan masalah, hal tersebut dapat dijadikan sebagai referensi lain untuk mengembangkan penelitian lebih lanjut, misalnya mengembangkan model pembelajaran untuk mengubah perilaku pemecahan masalah siswa menjadi lebih baik agar kemampuan pemecahan masalah dapat meningkat. Selain itu, siswa yang mengalami kecemasan matematika tinggi cenderung kesulitan dalam mengerjakan masalah matematika kontekstual, sehingga dibutuhkan penelitian lebih lanjut untuk mengurangi kecemasan matematika siswa agar dapat lebih baik dalam menyelesaikan masalah matematika kontekstual.

\section{DAFTAR PUSTAKA}

Adhimah, O., \& Ekawati, R. (2020). Perilaku Pemecahan Masalah Siswa SMK dalam Menyelesaikan Masalah Kombinatorika Ditinjau dari Kecemasan Matematika. Jurnal Cendekia : Jurnal Pendidikan Matematika, 4(1), 346-352. https://doi.org/10.31004/cendekia.v4i1.211

Anggo, M. (2011). Pemecahan Masalah Matematika Kontekstual Untuk Meningkatkan Kemampuan Metakognisi Siswa. Jurnal Edumatica, 01(2), 35-42.

Auliya, R. (2016). Kecemasan Matematika dan Pemahaman Matematis. Jurnal Formatif 6(1):12-22. http://dx.doi.org/10.30998/formatif.v6i1.748

Aunurrofiq, M., \& Junaedi, I. (2017). Kecemasan Matematik Siswa dalam Menyelesaikan Soal-Soal Pemecahan Masalah. Unnes Journal of Mathematics Education Research, 6(2), 157-166.

Avcu, R., \& Avcu, S. (2010). 6Th Grade Students' Use of Different Strategies in Solving Ratio and Proportion Problems. Procedia - Social and Behavioral Sciences, 9, 1277-1281. https://doi.org/10.1016/j.sbspro.2010.12.320 
Aziz, S. N. A., Fuad, Y., \& Ekawati, R. (2018). Problem Solving Behaviors of Grade Seven Students Focusing on Negative Integers. 157(Miseic), 248-252. https://doi.org/10.2991/miseic-18.2018.60

Dacey, J. S., Mack, M. D., \& Fiore, L. B. (2000). Your Anxious Child: How Parents and Teachers Can Relieve Anxiety in Children. Diambil 20 November 2019, dari Google Books

Freedman, E. (2017). Definition of Math Anxiety. Diambil $7 \quad$ Desember 2019, dari http://www.mathpower.com/anxtest.htm

Hardi, J., Hudiono, B., \& Mirza, A. (2013). Deskripsi Pemahaman Siswa pada Permasalahan Perbandingan dan Strategi Solusi dalam Menyelesaikannya. Jurnal Pendidikan dan Pembelajaran, 2(5), 1-11.

Hegarty, M., Mayer, R. E., \& Monk, C. a. (1995). Comprehension of Arithmetic Word Problems: A Comparison of Successful and Unsuccessful Problem Solvers inconsistent problems with those of problem solvers who do. Journal of Educational Psychology, 87(1), 18-32.

Karasel, N., Ayda, O., \& Tezer, M. (2010). The relationship between mathematics anxiety and mathematical problem solving skills among primary school students. Procedia - Social and Behavioral Sciences, 2(2), 5804-5807. https://doi.org/10.1016/j.sbspro.2010.03.946

Mahmood, S., \& Khatoon, D. T. (2011). Development and Validation of the Mathematics Anxiety Scale for Secondary and Senior Secondary School Students.. British Journal of Arts and Social Sciences, 2(2), 169179.

Memnun, D. S., Hart, L. C., \& Akkaya, R. (2012). A Research on the Mathematical Problem Solving Beliefs of Mathematics, Science and Elementary Pre-
Service Teachers in Turkey in terms of Different Variables. International Journal of Humanities and Social Science, 2(24), 172-184.

Nelissen, J. M. C. (1999). Thinking skills in realistic mathematics. In J. H. M. Hamers, J. E. H. Van Luit, \& B. Csapo (Ed.), Teaching and Learning Thinking Skills (hal. 189-214). Swets\&Zeitlinger.

Pape, S. J. (2004). Middle School Children's Behavior : A Cognitive Analysis from a Reading Comprehension Perspective. Journal for Research in Mathematics Education, 35(3), 187-219.

Peraturan Menteri Pendidikan Nasional Republik Indonesia No. 58 tahun 2014.

Siswono, T. Y. E. (2008). Model pembelajaran matematika berbasis pengajuan dan pemecahan masalah untuk meningkatkan kemampuan berpikir kreatif. Surabaya: Unesa university press.

Tatiana, Nerru P. M., Wiwik W. (2018). Pengaruh Kecemasan Matematika (Mathematics Anxiety) Terhadap Hasil Belajar Matematika Siswa SMP. Aksioma. Vol. 9, No 1, Juli 2018. e-ISSN 2579-7646.

Wahyuningrum, A. S., Suryadi, D., dan Turmudi, T. (2019). Learning Obstacles among Indonesian Eighth Graders on Ratio and Proportion. Journal of Physics: Conference Series, 1320(1). https://doi.org/10.1088/1742-6596/1320/1/012046

Winarso, W. (2014). Problem Solving, Creativity dan Decision Making Dalam Pembelajaran Matematika. . Eduma, 3(1), 1-16.

Zakaria, E., \& Nordin, N. M. (2008). The effects of mathematics anxiety on matriculation students as related to motivation and achievement. Eurasia Journal of Mathematics, Science and Technology Education, 4(1), 27-30. https://doi.org/10.12973/ejmste/75303

Zulkardi, \& Ilma, R. (2006). Mendesain sendiri soal kontekstual matematika. Prosiding KNM13 Semarang, $1-7$. 